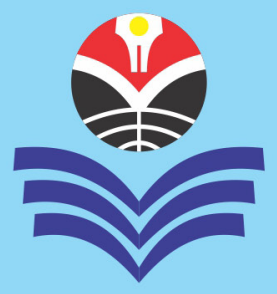

\title{
Short-Term Strategy for Developing School-Based Lesson Study towards Learning Community at Special Education in Indonesia
}

\begin{abstract}
The implementation of Lesson Study provides a new perspective in the context of pedagogy in schools among teachers. This article proposes a short-term strategy that can be implemented in developing School-Based Lesson Study at school towards the establishment of learning community at Special Education. In School-Based Lesson Study, the teachers from various backgrounds have done Lesson Study activities together regardless the subjects they teach. The strategy that can be implemented by the school in the first year is to train the core staffs, to clarify the vision on child education, to have similar perception of teachers, and to create the system of lesson activities. The second and the third year is the time for evaluating the progress of the implementation of School-Based Lesson Study at Special Education based on certain characters, namely the pupils lesson and study from each other, and the teachers learn from each other through meeting in order to improve their teaching skill.
\end{abstract}

KEY WORD: School-Based Lesson Study; Learning Community; Special Education; Short-Term Strategy; Activities Together.

ABSTRAKSI: "Strategi Jangka Pendek untuk Mengembangkan Lesson Studi Berbasis Sekolah Menuju Masyarakat Pembelajar di Sekolah Luar Biasa di Indonesia". Implementasi Lesson Studi menyediakan perspektif baru dalam konteks pedadogis kepada guru-guru di sekolah. Artikel ini mengusulkan sebuah strategi jangka pendek yang dapat diterapkan dalam mengembangkan Lesson Studi Berbasis Sekolah menuju terbentuknya masyarakat pembelajar di SLB (Sekolah Luar Biasa). Lesson Studi Berbasis Sekolah di mana guru dari berbagai bidang studi bersama-sama melakukan kegiatan Lesson Studi tanpa melihat latar belakang bidang studi yang dipegang oleh guru. Strategi yang diterapkan pada tahun pertama yang dapat dilakukan oleh sekolah adalah membina "core staff" (tenaga inti), mengklarifikasi visi pendidikan anak, menyamakan persepsi unsurunsur keahlian guru, dan menciptakan sistem aktivitas pembelajaran. Pada tahun kedua dan ketiga, mengevaluasi tingkat keberhasilan pelaksanaan Lesson Studi Berbasis Sekolah di SLB berdasarkan karakteristik, yaitu anak-anak saling menyimak dan saling belajar satu sama lain, dan para guru saling belajar satu sama lain melalui pertemuan untuk mengasah keterampilan mengajar yang kreatif.

KATA KUNCI: Lesson Studi Berbasis Sekolah; Masyarakat Pembelajar; Sekolah Luar Biasa; Strategi Jangka Pendek; Aktivitas Bersama.

About the Author: Dr. Bastiana is a Lecturer at the Faculty of Education UNM (State University of Makassar) in Makassar City, South Sulawesi, Indonesia. For academic interests, the author is able to be contacted via e-mail address at: bastiana@unm.ac.id

How to cite this article? Bastiana. (2017). "Short-Term Strategy for Developing School-Based Lesson Study towards Learning Community at Special Education in Indonesia" in MIMBAR PENDIDIKAN: Jurnal Indonesia untuk Kajian Pendidikan, Vol.2(2), September, pp.185-196. Bandung, Indonesia: UPI [Indonesia University of Education] Press, ISSN 2527-3868 (print) and 2503-457X (online).

Chronicle of the article: Accepted (March 11, 2017); Revised (May 13, 2017); and Published (September 30, 2017). 


\section{INTRODUCTION}

The efforts on improving the quality of education for children with special needs are done sustainably by government, school, and community. Every component of implementation of education in the system must be improved in accordance with the fast development of science and technology. The internal as well as external components of educational process must have equal treatment.

Special Education is a kind of educational service for the pupils with special needs that cannot be separated from the effort for the improvement and betterment of quality of education (Lynch, 1994; Mazurek \& Winzer, 1994; and Cortiellia, 2006). The school principal, teachers, education personnel, and students, together with parents as part of school system at Special Education, have to work collaboratively to make the quality improvement come true.

One of the important things to do in the implementation of education is to develop learning community that make the individuals involved at Special Education learn. Not only students but also teachers are required to learn as well as school principal, education personnel, and parents. The learning community is said to exist, when every component thinks that learning is a need (Morrissey, 2000; and Fischer \& Sugimoto, 2007).

According to Manabu Sato (2014a), school being in the learning community atmosphere has some characteristics, namely: (1) the pupils learn from each other and develop well; (2) the teachers as the experts also learn from each other and develop well; and (3) the parents as the community support and involve themselves in school reform by learning each other and develop well (Sato, 2014a).

Developing the situation and condition in learning community at Special Education is not easy, because it needs the change of mindset of the people that has been practice for years. So that it needs a strategy to change the mindset of the individual existing at Special Education. The short term strategy that can be done is through School-Based Lesson Study. Why the lesson study?

Survey results show that the implementation of Lesson Study provides a new perspective in the context of pedagogy in schools among teachers (Lewis, 2002; and Isoda, 2010). At the same time, the implementation of Lesson Study also increases student participation in learning activities in the classroom (Matanluk, Johari \& Matanluk, 2013). How is the short-term development of School-Based Lesson Study toward learning community at Special Education?

This question, by using the quantitative and qualitative studies (Zuljan \& Vogrinc eds., 2010; Dodge, 2011; and Johnson, 2011) and theoritical reviews, becomes the guidance in developing short-term strategy of School-Based Lesson Study towards learning community at Special Education (Gaspar, 2010; anf Gablinske, 2014).

\section{FINDINGS AND DISCUSSION \\ Learning Community. Learning} community is the objective of Lesson Study approach. S. Hord (2003) describes learning community as the well-integrated community in educational atmosphere. It develops a community that has similar perception on education, so that each individual involved will be dependent and functional one another (Hord, 2003:16).

The view on learning community as an approach was stated by K. Bielaczyc \& A. Collins (2016) that learning community is an approach discussion the solution to the complicated problems faced by the students, things outside themselves (Bielaczyc $\&$ Collins, 2016:3). Communicating and working with people from various backgrounds and views, and sharing what they have learned from others. Every 
problem faced by the students is discussed together, communicated with other teachers, school principal, education personnel, and parents, to find out the best solution.

The product is the more effective and efficient learning, because it is discussed with school community. When this is done, it means that the school has developed learning community. N. Robinson \& R. Leikin (2012) argue that collaborative noticing, collaborative awareness, and brainstorming are the core mechanisms of teacher change in the course of Lesson Study (Robinson \& Leikin, 2012).

The school as the community is stated by S. Hord (2003), viewing that learning community is bringing community situation by making use of available resources, namely human and non-human resources (Hord, 2003:6). In other words, bringing the people in the community to the school environment to improve the learning process for the students and by developing curriculum. The school principal, teachers, education personnel, and students are members of school community, who will work together to develop school community (Pont, Nusche \& Moorman, 2008). They work together and help each other to achieve the school objectives.

The school that can be said as learning community, according to Manabu Sato (2014a), is characterized by the acceptance of the teachers on the students as they are and the attitude of teachers and students (Sato, 2014a). The teacher who accepts the students as they are means that the teachers are not allowed to discriminate the students, even though the facts show that the students are different. It is not the reason for the teachers to differentiate their acceptance on the students. Therefore, when the teachers are in the classrooms, they have to be able to understand the feeling and condition of the students from the facial expression and not to let the students be alone (Sato, 2014a).

The attitude and behavior of the teachers and students are described also by Manabu Sato (2014b), stating that the teachers do not blame each other, but help each other (Sato, 2014b). Therefore, the teachers need to improve their professionalism for better collegiality among them. The main task of the school is to develop and improve the attitude. Judging from the students, the attitude expected is the students do not let their friends alone, but they care and help each other. The school must develop and educate the students to have that attitude. It emphasizes more on the attitude that the teachers must have and the school if the school wants to develop learning community.

T.A. Astuto et al. (1993), as cited also by S. Hord (2003), propose three communities developed at school environment, namely: (1) professional community that is the teachers; (2) learning community, they are teaches and students, and among the students themselves, inside or outside the classrooms; and (3) stakeholders community. The proposal is focused on what is said by T.A. Astuto and his colleagues named "learners professional community". This view is wider, because it also involves the stakeholders as part of school community ( $c f$ Astuto et al., 1993; and Hord, 2003:16). Without stakeholders, the school means nothing because there is no place for placing the outputs from learning community at school.

Different from T.A. Astuto et al. (1993), Manabu Sato (2014a) did not mention stakeholder, but there were parents and community as part of learning community coming from outside the schools (cf Astuto et al., 1993; and Sato, 2014a). In fact, stakeholders are also members of community, but they refer more functionality between schools and stakeholders.

I. Rosyida \& F. Nasdian (2011) indicated the importance of stakeholders by emphasizing that a program will have real 
effect, when every stakeholder participate on every stages of implementation (Rosyida \& Nasdian, 2011:68). It means that the school will have effect and function as the place for providing the students with knowledge and skills, if the stakeholders participate from planning up to the distributing the students to the community.

Lesson Study. Lesson Study approach was originally developed in Japan through researches to find out its effectiveness in learning process. The Lesson Study approach undergoes some changes in line with the changes in Japan. R. Arani at al. (2010) find out that Lesson Study has significant influence on the development of culture and professionalism in Japan (Arani et al., 2010:184).

The definition of Lesson Study is stated by Masaaki Sato (2014). He states that Lesson Study is a model of improving the professionalism of teachers through the study of instruction collaboratively and sustainably based on collegiality principles to develop learning community (Sato, 2014). Lesson Study is not a technique or method of teaching, but it is a model for improving the teachers. In Lesson Study, the teachers may implement various teaching method that are appropriate to the materials taught. The instruction in Lesson Study is done collaboratively between the teachers, not only the teachers of the same educational background but also those from different educational backgrounds directed by the school principal by using the collegiality principles as the base. Researchs that have been conducted on Lesson Study indicates that it has strong potential for effective collaborative planning ( $c f$ Lenski \& Caskey, 2009; and Sato, 2014).

According to R. Arani et al. (2010), there are three core points of Lesson Study in the implementation in education. First, it is very important that the teachers should work collaboratively in planning the lesson and give feedback and no teachers dominate as the leader of the implementation of Lesson Study. There should be not teachers who feel smarter than others. All teachers learn from and another and give ideas in the development of instructional planning and give feedback at the time of redesigning instruction.

Second, the teachers have similar levels, need to clarify their views on education and learning for students; teachers should present their lesson plan developed collaboratively and use basic approach in teaching. Lesson plan developed collaboratively should be used by the teachers in teaching.

The final consideration, third, is that Lesson Study should be understood as the regular training and process, and that problem cannot be solved only in one meeting session but through some repeated trainings. In every session, the teachers will find out something new from the students behavior. Through repeated training and process of Lesson Study, the experienced teachers help the unexperienced once to learn (Arani et al., 2010).

Through the process of collaborative planning, observation, analysis, and imagining collaborative learning, the teachers may see the aspects of students learning from insight of others and ourselves; and compare the observed instruction in class and the lesson expected while planning (cf Arani et al., 2010; and Dudley, 2011).

School-Based Lesson Study at Special Education School. Special Education school is a kind of educational service for the pupils with special needs. At Special Education school, the pupils with special needs are educated together with other pupils with special needs, not only the pupils with the same special needs but also with different ones. They are educated in the same environment and in the same education management.

In the implementation of special 
education at Special Education school, especially for basic level, the learning process has the system of thematic and classroom teachers. Consequently, there is only one teacher who teaches all subjects in every classroom, except religion and sport teachers. Therefore, Lesson Study approach which is more relevant to be implemented at Special Education school is School-Based Lesson Study approach.

School-Based Lesson Study approach is the Lesson Study implemented by involving school principal, teachers regardless the subjects they teach. The teachers with various backgrounds work collaboratively to improve their teaching competence in classroom through SchoolBased Lesson Study. Even though this is the case at one school, it shows how the teachers are able to work collaboratively for one subject (Akiko, 2015).

Even though the level is different, every teacher has the same objective, that is the professional development of teachers to develop learning community. According to C. Lewis \& J. Hurd (2011), School-Based Lesson Study is done by developing the instructional theme as the whole, so that it provides collaborative experience which is very important for teachers to link the work of teachers between schools (Lewis \& Hurd, 2011). After that, the teachers create small team to plan the lesson in accordance with the development of agreed theme.

At Special Education school, every level of education has certain theme that can be developed collaboratively by the teachers, even though the teachers do not teach the theme intended. Therefore, C. Lewis \& J. Hurd (2011) again give examples, the teachers from various disciplines may work collaboratively to improve the writing competence of the students or their strategy to improve the students understanding on non-fiction (Lewis \& Hurd, 2011).

The agreement is goten from the collaboration of the same level between the teachers with different educational background or inter class. K. Akiko (2015) states that there are three important factors in developing collaboration in School-Based Lesson Study. Firstly, under the coordination of the chairperson, all teachers are their own roles. The second factor is that all teachers must do Lesson Study every year, so that many teachers are involved in Lesson Study. The third factor is that there are several meetings done by the teachers outside the class hours (Akiko, 2015).

The implementation of School-Based Lesson Study can be seen from the characteristics. Masaaki Sato (2012 and 2014) states that the characteristics of School-Based Lesson Study are, firstly, the activity of the Lesson Study is the opportunity for the teachers to gain knowledge on the teaching materials. There are many things that can be gained from School-Based Lesson Study dealing with learning materials. The teachers are able to enrich their teaching materials through collaboration of teachers (Sato, 2012 and 2014).

The teachers at Special Education school are able to collaborate in designing the materials in accordance with the need of the students based on the ideas and suggestions given by other teachers. The teacher may have the inputs or suggestions when they do open class at least once a year. The open class is the requirement for the teachers who do open class. During the open class session, all teachers observe and take note important events done by the students. The results of observations are then discussed in the reflection session. Special Education teachers are required to do open class at least once a year.

Secondly, Lesson Study activities is interdisciplinary subjects. Every meeting, not only on the session of redesign but also on reflection session, is attended by teachers from different levels and by different subjects. Inter-subject and inter lever of 
classes are very appropriate done at Special Education (Sato, 2012 and 2014).

Short-Term Development Strategy of School-Based Lesson Study in Special

Education. The development of SchoolBased Lesson Study in Special Education can be improved through cooperation between the principal as policy makers, teachers in the classroom and across fields of study, and parents. In public schools, there have been several schools that have implemented School-Based Lesson Study, but there are still many that are not successful. Masaaki Sato (2012) views that the failure was caused by the management of the school by the principal and School-Based Lesson Study activities that do not fully improve the quality of daily instructions (Sato, 2012).

It is necessary for short-term strategy that can be done by schools in improving students' achievement and in order to develop the competence of teachers towards learning community. According to Masaaki Sato (2014) and Manabu Sato (2014a), short-term strategy to make changes in the school through the Lesson Study towards learning community is done in three years as explained below:

First Year. Activities that can be done in the first year in order to establish a learning community through School-Based Lesson Study are:

Firstly, Fostering Core Staff to Undertake Activities of Lesson Study. The first thing to do is to create staff to be the pioneer of Lesson Study at schools. The number of the core staffs should be more than 5 people at each school, including the principal. As the core personnel, principals and teachers selected must have good understanding on Lesson Study and have a commitment to do school reformation with Lesson Study. They are required to coordinate teachers and to develop the framework for the implementation of Lesson Study at school (Sato, 2014; and Sato, 2014a).
In contrast to Masaaki Sato (2014) and Manabu Sato (2014a), C. Lewis \& J. Hurd (2011) stated that the first thing to do at school in creating Lesson Study is to recruit members of the group. The recruitment of members of the group is done by persuading all the teachers to read articles or books or watch videos on Lesson Study to build awareness on Lesson Study. Once the awareness of Lesson Study is developed, it will be easier to take and to give inputs and feedbacks on reflection or redesign session (cf Lewis \& Hurd, 2011; Sato, 2014; and Sato, 2014a).

Secondly, Clarifying the Vision of Child Education. According to Masaaki Sato (2014), the vision of implementation of Lesson Study is to ensure the learning for every pupil. Every child should not remain silent and teachers should not let it that way if it happens on children. The child should be persuaded to interact and collaborate with their peers in group, especially children with special needs who are likely switch attention easily. This vision should be understood by the principal and the teacher when they are in class (Sato, 2014).

Dissemination of vision of Lesson Study implementation need to be done, so that principals and teachers understand the condition of the children, such as to deliver the vision at every meeting.

Thirdly, Elements of a Common Perception Skills of Teachers. Every teacher has a particular expertise. The expertise of every teacher can be understood from any reflection or the redesign, so that teachers can exchange ideas and experience in developing instruction in the classroom. Making the perception similar does not mean unifying opinion on teaching methods or techniques, but what is obtained from the exchange of ideas will be developed by teachers according to the grade level and respective field of study (Sato, 2014; and Sato, 2014a).

C. Fernandez \& M. Yoshida (2004) 
describe the importance of Lesson Study for teachers in preparing the material, and that Lesson Study provides the opportunity for teachers to discuss the material they use for teaching; and, thus, teachers can improve their understanding on the materials (Fernandez \& Yoshida, 2004).

To reach an agreement within the framework of shared perception among teachers, the meetings can be scheduled once a month, such as on Thursdays of the first week of each month. At this meeting, the school principal and the teachers must be present to provide inputs and suggestions related to the learning and preparation of open lesson.

According to Masaaki Sato (2014), on the School-Based Lesson Study, every teacher must do an open lesson at least once a year, then on reflection forum, participants discuss: where does the instruction take place? What materials are found to be difficult for the students? And where there is potential for the development of learning according to the facts that have been observed? These questions should be discussed to find solutions. Feedback and suggestions that emerge from the discussions is the input of teachers to create appropriate learning conditions of students with special needs (Sato, 2014).

Fourthly, Creating a System of Lesson Study Activities to Improve Teachers' Competence. It is necessary to conduct Lesson Study activities in accordance with the vision, mission, and school support to improve the competence of teachers and to ensure the sustainability of the activities of the Lesson Study. Stages of Lesson Study: plan-do-see, and redesigning, are understood and have been implemented by all teachers in Special Education.

Similarly, when in class, Lesson Study is done through certain activities. Teachers have implemented the seating plan with the letter U, so that the teacher can see all students without hindrance and to facilitate interaction among students. The students are divided into some groups based on the level of the students. For grades 1-3 students, make them work in pairs consisting of male and female students. For grades 4-6, they are divided into some four member groups consisting two male and two female students sitting crossing each other. The purpose of this grouping is to form mutual learning and interaction among them (Sato, 2014).

Second and Third Year. The learning community is expected to have been established on the second year at the Special Education (Morrissey, 2000; Fischer \& Sugimoto, 2007; and Sato, 2014a). The implementation can be seen:

Firstly, Children Listen to and Learn from One Another. Mutual learning is a process of collaboration between students in completing the tasks assigned by the teacher, so that the task can be done well by the students. According to M. Ueno (2014), through mutual learning, students not only share what they have understood but also what they do not understand and what they find difficult through understanding and inspiring each other (Ueno, 2014). In the classroom implementation, there are no longer children who remain silent, but they go on working, for example, asking their friends in group or the teacher when they do not understand the materials.

Secondly, Teachers Learn from One Another through Meetings (Actual Case Study of Teaching and Learning Process). The activities do not only require the students to learn, but also the teachers are required to learn from each other. School develops schedule to hold regular meetings for teachers. At the meeting, the teacher states problems encountered both in designing and in implementing the teaching and learning process. Every teacher is encouraged to give inputs/ideas to solve problems faced by their colleagues.

Thirdly, Developing Creative and Dynamic Teaching Skills in Accordance 
with the Conditions of the Students. Through mutual learning, teachers are able to improve their competence in designing and implementing implement learning process. At the end of the learning process, it can be produced more creative and innovative instruction in accordance with conditions of students with special needs. Po Yuk Ko (2014) shows that in a LS (Lesson Study) platform, teachers' teaching act and their interaction with theorists contributed to a dual process of developing the practice as well as the theory itself. The results of students' learning serve as evidences for the claim that "contrast should precede generalization" as the theory suggested (Ko, 2014).

If everything runs as expected in the second year, the third year is mainly focused more on the development of School-Based Lesson Study to wider scope, namely to 2 or 3 schools. However, if the learning community cannot be developed as expected on the second year, the third year should be emphasized on the improvement.

Discussion. The implementation of shortterm strategy to develop a School-Based Lesson Study towards learning community at Special Education is not easy and surely will face many problems. There are many factors influencing it, such as school principal leadership, mind-set of teachers, school facilities, and infrastructure as well as support from the government and parents.

According to Masaaki Sato (2014), the principal needs to have strong commitment to reform schools through School-Based Lesson Study (Sato, 2014). Therefore that principals are in charge of: (1) bringing together the idea on the importance of school reform, so that there will be no pros and cons; ( 2 paying good care and attention the teachers and students; (3) understanding the implementation of Lesson Study; and (4) thinking of Lesson Study not as a routine activity (Sato, 2014).

The principal has a very vital role in the School-Based Lesson Study, because he/she is the first goes to person if Lesson Study is carried at SLB (Sekolah Luar Biasa or Special Education). The results of the analysis done by A. Supriatna et al. (2013) concluded that if the principals understood how the Lesson Study began in the school from the beginning, it will become last long activity (Supriatna et al., 2013).

In addition to school principal, the other personnel that may need attention are the core staffs in the development of School-Based Lesson Study at Special Education. This small group of personnel is very important, because they will become motor for the sustainability of activities. Again, A. Supriatna et al. (2013) emphasize the importance of this small group for disseminating the Lesson Study at school, besides convincing colleagues and principals to change Lesson Study from sporadic activity into systemic activity (Supriatna et al., 2013). If the core personnel are able to play their role well, the Lesson Study will run as expected.

Teachers also play an important, because they are the actors of the Lesson Study in class. And the most important thing to deal with is how to change the teachers from theoretically capable to become the ones who are able to implement the Lesson Study in practice based on sustainable participation and conducive atmospheres (Gutierez, 2015).

So far, E. Soto et al. (2015) said that LS (Lesson Study) reinforces these two complementary movements: (1) the practical theorizing movement, the reflexion on action to discover the implicit believes, habits, attitudes, and emotions underlying the practice; and (2) the experimentation of the new theory to form the new habits, beliefs, attitudes, and emotions that support the development of a new form of teaching (Soto et al., 2015). This second movement needs more time and adequate teaching context, confirming the long spiral cycle of LS.

When teachers participate in a Lesson Study community, they verbalize the 
mental dialogue that usually occurs during individual planning. Further, the group interactions provide multiple ways to envision the lesson. As the teachers negotiate their final plan, they are able to examine a wider range of possibilities for lesson instructions, possible student responses, and how to evaluate student learning. Ideas are shared, examined, negotiated, and decided upon (Lenski \& Caskey, 2009).

Lesson Study should be introduced not only at the time a teacher has taught, but should be initiated at the time a candidate for the teacher. This means that the exceptional education teacher candidates have been provided with theoretical and practical lessons for college studies.

Finally, P. Lamb \& Po Yuk Ko (2016) concluded that the richness and value of embracing Lesson and Learning Study programs within initial teacher education; whilst being mindful of the challenges and constraints inherent in the nature of national policies towards the training of teachers (Lamb \& Ko, 2016). Briefing on Lesson Study that began in the teacher education program at the college cannot be separated from government policy to improve the competence of exceptional education teacher.

\section{CONCLUSION}

A short-term strategy that can be done in developing School-Based Lesson Study at Special Education is done on the first year, the second year, and the third year. Among the activities that can be done on the first year are to develop core staffs, to clarify the vision of child education, to have similar perception of teacher expertise, and to create a system of lesson activities. The second and third year are intended to evaluate the level of success of the school-based implementation of Lesson Study in Special Education based on the characteristics of the children, namely they listen to each other and learn from each other, teachers learn from each other through meetings, and development of creative teaching skills.

Short-term strategy for developing learning community at Special Education through School-Based Lesson Study should be supported by a commitment of school principals in reforming school through School-Based Lesson Study. In addition, the role of core staffs in disseminating the Lesson Study at Special Education needs to be improved. If all the elements work collaboratively, then, the short-term strategy for developing learning community through School-Based Lesson Study at Special Education can be achieved. ${ }^{1}$

\section{References}

Akiko, K. (2015). “A Case Study of School-Based Lesson Study at a Japanese Public Elementary School for Foreign Language Activities" in The Tsuru University Revie, No.81, pp.159-187.

Arani, R. et al. (2010). "Lesson Study as Professional Culture in Japanese Schools: An Historical Perspective on Elementary Classroom Practices" in Japan Review, 22, pp.171-200.

Astuto, T.A. et al. (1993). Challenges to Dominant Assumptions Controlling Educational Reform. Andover, MA: Regional Laboratory for the Educational Improvement of the Northeast and Islands.

Bielaczyc, K. \& A. Collins. (2016). "Learning Communities in Classrooms: A Reconceptualization of Educational Practice" in N.J. Mahwah [ed]. Instructional Design, Theories, and Models, Volume II. New Jersey: Lawrence Erlbaum Associates.

Cortiellia, C. (2006). NCLB and IDEA: What Parents of Students with Disabilities Need to Know and

\footnotetext{
${ }^{1}$ Statement: I, hereby, declare that this paper is my original work and not a product of plagiarism from any books or journals that have been published. The citation is stated and shown in the References. I confirm that this manuscript has not been published elsewhere and is not under consideration in whole or in part by another journal. I have also declared no potential conflicts of interest with respect to the research, authorship, and/or publication of this article. I received no financial support for the research and/or authorship of this article.
} 
Do. Minneapolis, MN: University of Minnesota, National Center on Educational Outcomes. Available online also at: http://www.ldonline.org/ article/11846/ [accessed in Makassar, Indonesia: October 9, 2016].

Dodge, Pamela R. (2011). "Managing School Behavior: A Qualitative Case Study" in Graduate Theses and Dissertations, 12038. Available online also at: http://lib.dr.iastate.edu/cgi/viewcontent. cgi? article $=3016 \&$ context $=$ etd [accessed in Makassar, Indonesia: October 9, 2016].

Dudley, P. (2011). Lesson Study: A Handbook. UK [United Kingdom]: University of Cambridge.

Fernandez, C. \& M. Yoshida. (2004). Lesson Study: A Japanese Approach to Improving Mathematics Teaching and Learning. Mahwah, New Jersey: Lawrence Erlbaum Associates Publishers.

Fischer, Gerhard \& Masanori Sugimoto. (2007). "Supporting Self-Directed Learners and Learning Communities with Sociotechnical Environments". Available online at: http://13d.cs.colorado. edu/ gerhard/papers/final-RPTEL.pdf [accessed in Makassar, Indonesia: March 2, 2017].

Gablinske, Patricia Brady. (2014). "A Case Study of Student and Teacher Relationships and the Effect on Student Learning" in Open Access Dissertations, Paper 266. Available online also at: http://digitalcommons.uri.edu/cgi/viewcontent. cgi? article $=1284 \&$ context $=0$ a diss [accessed in Makassar, Indonesia: March 2, 2017].

Gaspar, Sandra L. (2010). "Leadership and the Professional Learning Community" in Educational Administration: Theses, Dissertations, and Student Research, 43. Available online also at: http://digitalcommons. unl.edu/cgi/viewcontent.cgi? article $=1042 \&$ contex $\mathrm{t}=$ cehsedaddiss [accessed in Makassar, Indonesia: March 2, 2017].

Gutierez, S.B. (2015). “Collaborative Professional Learning through Lesson Study: Identifying the Challenges of Inquiry Based Teaching" in Issues in Educational Research, 25(2).

Hord, S. (2003). Professional Learning Communities of Continuous Inquiry and Improvement. Texas: Southwest Educational Development Laboratory.

Isoda, M. (2010). "Lesson Study: Problem Solving Approaches in Mathematics Education as a Japanese Experience" in PROCEDIA: Social and Behavioral Sciences, pp.17-27.

Johnson, Daniel R. (2011). “A Quantitative Study of Teacher Perceptions of Professional Learning Communities' Context, Process, and Content" in Seton Hall University Dissertations and Theses, 15. Available online also at: http://scholarship. $\underline{\text { shu.edu/cgi/viewcontent.cgi? article }=1025 \&}$ context $=$ dissertations [accessed in Makassar,
Indonesia: October 9, 2016].

Ko, Po Yuk. (2014). "Learning Study: The Dual Process of Developing Theory and Practice" in International Journal for Lesson and Learning Studies, Volume 3, Issue 3, pp.272-289. DOI available online also at: http://dx.doi.org/10.1108/ IJLLS-07-2014-0019 [accessed in Makassar, Indonesia: October 9, 2016].

Lamb, P. \& Po Yuk Ko. (2016). "Case Studies of Lesson and Learning Study in Initial Teacher Education Programmes" in International Journal for Lesson and Learning Studies, Volume 5, Issue 2, pp.78-83. DOI available online also at: http:// dx.doi.org/10.1108/IJLLS-02-2016-0005 [accessed in Makassar, Indonesia: March 2, 2017].

Lenski, S.J. \& M.M. Caskey. (2009). "Using the Lesson Study Approach to Plan for Student Learning" in Middle School Journal, 40(3), pp. 50-57.

Lewis, C. (2002). "Does the Lesson Study Have Future in the United States?" in Nagoya Journal of Education and Human Development, (1), pp.1-23.

Lewis, C. \& J. Hurd. (2011). Lesson Study: Step by Step How Teacher Learning Communities Improve Instruction. USA [United States of America]: Heinemann Portsmouth.

Lynch, James. (1994). Provision for Children with Special Educational Needs in the Asia Region. Washington, DC: World Bank Technical Paper Number 261, Asia Technical Series.

Matanluk, M., K. Johari \& O. Matanluk. (2013). "The Perception of Teachers and Students toward Lesson Study Implementation at Rural School of Sabah: A Pilot Study" in PROCEDIA: Social and Behavioral Sciences, Volume 90 [10 October], pp.245-250. Available online also at: https://doi. org/10.1016/j.sbspro.2013.07.088 [accessed in Makassar, Indonesia: October 9, 2016].

Mazurek, K. \& M.A. Winzer. (1994). Comparative Studies in Special Education. Washington, DC: Gallaudet University Press.

Morrissey, Melanie S. (2000). Professional Learning Communities: An Ongoing Exploration. Texas: Southwest Educational Development Laboratory. Available online also at: http://www.sedl.org/ pubs/change45/plc-ongoing.pdf [accessed in Makassar, Indonesia: October 9, 2016].

Pont, B., D. Nusche \& H. Moorman. (2008). Improving School Leadership, Volume 1: Policy and Practice. Australia: OECD Publications. Available online also at: https:/www.oecd.org/ edu/school/44374889.pdf [accessed in Makassar, Indonesia: October 9, 2016].

Robinson, N. \& R. Leikin. (2012). “One Teacher, Two Lessons: The Lesson Study Process" in International Journal of Science and Mathematics 
Education, Volume 10, Issue 1 [February], pp.139-161. DOI: 10.1007/s10763-011-9282.

Rosyida, I. \& F. Nasdian. (2011). "Society and Stakeholder Participation in Corporate Social Responsibility (CSR) Program and the Impact of Rural Community" in Jurnal Transdisiplin Sosiologi, Komunikasi, dan Ekologi Manusia, Vol.05, No.01 [April], pp.51-70, ISSN 1978-4333.

Sato, Manabu. (2014a). "Reformasi Sekolah dengan Learning Community: Visi, Filosofi, dan Sistem Kegiatan". Makalah yang Disampaikan dalam STOLL for ITTEP By JICA, Tokyo, Japan, translated by Author.

Sato, Manabu. (2014b). Mereformasi Sekolah: Konsep dan Praktek Komunitas Belajar. Tokyo: JICA Publication, Translation.

Sato, Masaaki. (2012). Dialog dan Kolaborasi di Sekolah Menengah Pertama: Praktek "Learning Community". Jakarta: Penerbit Pelita, Translation.

Sato, Masaaki. (2014). "Lesson Study untuk Reformasi Sekolah yang Berkesinambungan". Makalah yang Disampaikan dalam STOLL for ITTEP by JICA, Tokyo, Japan, translated by Author.
Soto, E. et al. (2015). "Lesson Study and the Development of Teacher's Competences: From Practical Knowledge to Practical Thinking" in International Journal for Lesson and Learning Studies, Volume 4, Issue 3, pp.209-223. DOI available online also at: http://dx.doi.org/10.1108/ IJLLS-09-2014-0034 [accessed in Makassar, Indonesia: March 2, 2017].

Supriatna, A. et al. (2013). "Pengembangan Pusat Reformasi Sekolah Melalui Lesson Study". Laporan Penelitian Tidak Diterbitkan. Bandung: Pusat Inovasi Pendidikan LPPM UPI [Lembaga Penelitian dan Pengabdian pada Masyarakat, Universitas Pendidikan Indonesia].

Ueno, M. (2014). "Pembelajaran Kolaboratif dan Pendidikan Demokrasi". Makalah yang Disampaikan dalam STOLL for ITTEP By JICA, Tokyo, Japan, translated by Author.

Zuljan, M.V. \& J. Vogrinc [eds]. (2010). Facilitating Effective Student Learning through Teacher Research and Innovation. Ljubljana: Faculty of Education. Available online also at: http://www. pef.uni-lj.si/ceps/knjiznica/doc/zuljan-vogrinc.pdf [accessed in Makassar, Indonesia: March 2, 2017]. 
BASTIANA,

Short-Term Strategy for Developing School-Based Lesson Study

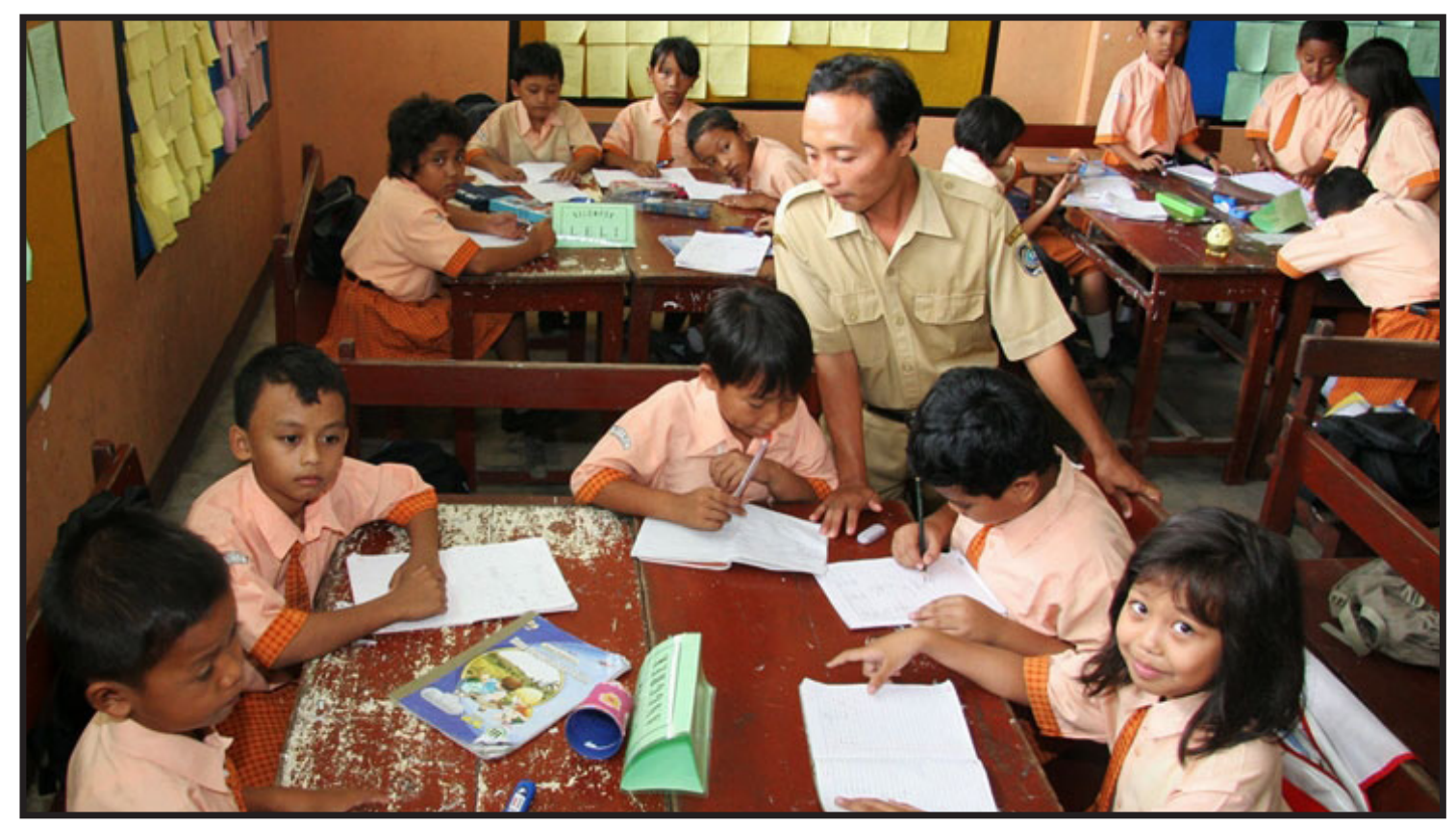

The Process of Education in Indonesia

(Source: http://www.worldbank.org, 2/3/2017)

Short-term strategy for developing learning community at Special Education through School-Based Lesson Study should be supported by a commitment of school principals in reforming school through School-Based Lesson Study. In addition, the role of core staffs in disseminating the Lesson Study at Special Education needs to be improved. If all the elements work collaboratively, then, the short-term strategy for developing learning community through School-Based Lesson Study at Special Education can be achieved. 